\title{
Observation: Botanical and other characteristics in Arctic salt-affected coastal areas
}

\author{
L.B. BRUCE, M.T. PANCIERA, R.G. GAVLAK, B.A. TILMAN, AND J.M. CADLE
}

Authors are assaciate professor of animal science, University of Nevada, Reno, School of Veterinary Medicine, Reno 89557; assistant professor of agronomy, associate professor of extension agronomy, and research techician of University of Alaska Fairbanks, 533 E. Fireweed Avenue, Palmer, Alaska 99645; professor, Tarleton State University; Department of Animal Science, Stephenville, Texas 76402.

\begin{abstract}
This study was designed to provide information on cover, botanical composition, and frequency of major plant species in a brood-rearing area used by migratory geese south of Howe Island on the Sagavanirktok River Delta near Prudhoc Bay, Alaska. The area is split by the Endicott road and the information was also used to gain preliminary information concerning the effect of the road on goose and caribou activity. Transects on the east and west sides of the access road at the base of the Endicott causeway were established to evaluate occurrences of vegetation, goose fecal pellets, caribou tracks, and coastal debris. The point intercept method characterized plant cover, species frequency, and botanical composition. The recorded occurrence of fecal pellets and tracks on the transects were used as estimates of the presence of geese and caribou. Vegetative cover was $21 \%$ west and $38 \%$ east of the road near the Endicott causeway base in 1991. The 3 species most prominent west of the road were Carex subspathacea Wormsk., Salix spp., and Puccinellia phryganodes (Trin.) Scribn. \& Merr. (botanical composition of 26, 23, and $21 \%$, respectively). East of the road, Salix spp. (43\%) dominated botanical composition followed by Carex aquatilis Wahlenb. (13\%) and Dryas integrifolia $M$. Vahl (11\%). The west and east sides differed botanically. Caribou tracks were observed in $60 \%$ of the transects on both sides of the road and goose fecal pellets were more prevalent on the west side $(86 \%)$ than on the east side $(48 \%)$. Geese pellets and caribou tracks occurred in different locations in the study area. Goose fecal pellets were from all goose species and may have included more than 1 year.
\end{abstract}

Key Words: North Slope Alaska, migratory geese, tundra, arctic, botanical composition, caribou.

The Endicott Development Project is in the central portion of the Sagavanirktok River delta, east of Prudhoe Bay on the North Slope of Alaska. During the planning and permitting for this project, federal resource agencies, particularly the US Fish and

Research was funded in part by a grant form British Petroleum (Alaska) Inc. Manuscript accepted 8 Oct. 1994.
Wildlife Service, expressed concern over direct and indirect impacts on migratory geese that nest on Howe Island. Behavioral reactions of the migratory geese to project facilities and activities and the effects on geese movements during brood-rearing were monitored by the US Army Corps of Engineers Endicott Monitoring Program. The US. Fish and Wildlife Service also expressed interest in the potential impacts on geese from the loss of brood rearing habitat that was covered by the Endicott access road. In response, BP Exploration (Alaska) Inc. initiated studies in 1990 (Wilkinson and Kertell 1991) to examine the distribution of vegctation consumed by migratory geese during brood-rearing and to quantify the amount of brood-rearing habitat altered by the Endicott road. Their technique used remote sensing techniques and measured vegetation groupings rather than individual plant species.

Techniques are available to estimate biomass needed by geese for growing, moulting, and brood-rearing (Giroux, et al. 1984). Chapin et al. (1975) showed that nutrient content of plants in Barrow, Alaska changed over the course of a summer. Some studies have been conducted to quantify both the nutrient content and species of plants that Crackling Geese consume (Derksen et al. 1982; Harwood, 1977; Sedinger and Raveling, 1984). Sedinger (1984) and Burgess and Richie (1988) measured the nutrient content of some of the major plant species occurring in the Prudhoe Bay area in relation to goose nutrient requirements. Nutrient content, in conjunction with quantitative data of plant species occurring near the Endicott road, could be used as the beginning of an estimate of the area's nutrient worth to wildlife. This would help quantify habitat loss by road building and other development activities.

Eberhardt et al. (1982) described the Prudhoe Bay area in general terms. There is no specific information available describing the habitat in the type of salt-affected coastal tundra formed near Prudhoe Bay. This study was designed to provide quantitative information on the vegetation present in this salt-affected coastal tundra. Specific objectives were to characterize the frequency of major plant species in the area, botanical composition, and cover. Quantification of the nutrient value of the habitat will ultimately require additional information, such as nutrient quality of individual plant species and the use by grazers. Additional objectives were to develop preliminary estimates of the effect of the road or 
the vegetation on goose or caribou activity as indicated by caribou tracks and goose pellets.

\section{Materials and Methods}

The study area was Arctic coastal tundra in the Endicott Development Project near the central portion of the Sagavanirktok River delta, east of Prudhoe Bay $\left(70.15^{\circ} \mathrm{N}\right)$ on the North Slope of Alaska. The site was from sea level to $4 \mathrm{~m}$ of elevation and a maximum of $750 \mathrm{~m}$ from the ocean. During periods of strong north winds, the sampling site is inundated with salt water. The site was dominated by slightly alkaline $(\mathrm{pH} 7.3)$ sandy loam soils with sparse vegetation. The specific area studied was a small peninsula spilt by the elevated gravel Endicott service road (Fig. 1). The study area on the west side is approximately $750 \mathrm{~m}$ by $300 \mathrm{~m}$ and has a long gradual slope to the ocean.. The east side is slightly smaller and higher in elevation $(4 \mathrm{~m})$ and has an abrupt drop of about $3.5 \mathrm{~m}$ to the ocean.

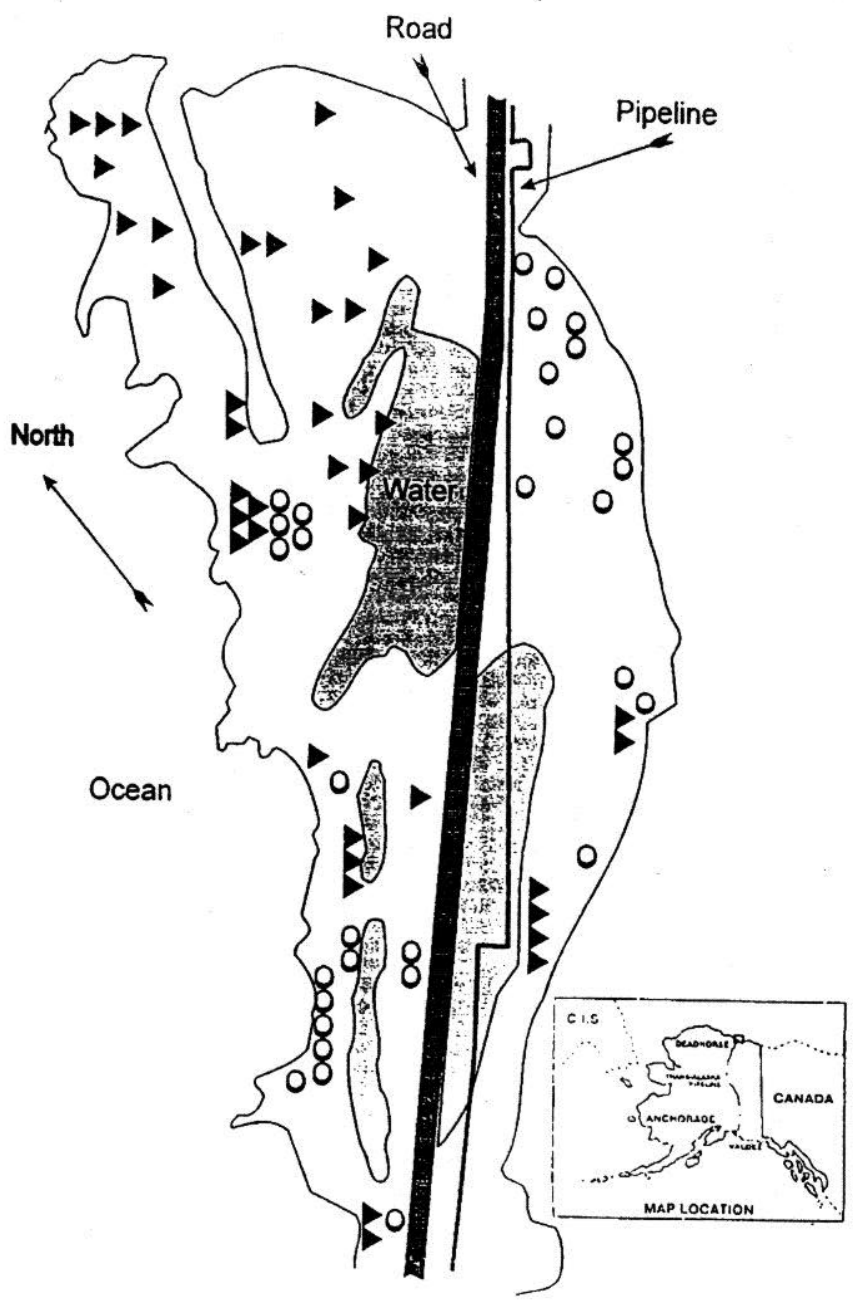

Fig. 1. Specific map of transect location. Triangles represent goose pellets and where they were found on transects indicating areas used by geese and circles represent tracks left by caribou. Each triangle or circle represents 3 individual droppings or tracks. Single droppings or tracks do not appear. The entire area is surrounded by ocean.
Line transects, $35 \mathrm{~m}$ apart and perpendicular to the road, 21 on the east side and 22 west side of the road, were established near the base of Endicott causeway (Fig. 1). Transects extended from the road to the ocean and were variable in length. Head stakes were established at the roadside with intermediate stakes approximately $30 \mathrm{~m}$ apart. The point intercept method was used, identifying species of plant or other objects occurring every $0.15 \mathrm{~m}$. The total number of observations was greater than 40,000 . The transect data were used to determine plant cover, botanical composition (relative abundance of species), distribution of plant species in the areas (frequency of transect occurrence), and animal activities within the areas. Data were compiled and expressed as percentage of plant cover, botanical composition, and frequency. Frequency was calculated for each plant species and nonbotanical items by calculating the percentage of transects containing that plant specie or non-botanical item. Fecal material or tracks were used as estimates of animal activity. Goose species and specific years of deposit or imprint could not be determined. Droppings and tracks may have disappeared at different rates in different micro habitat sites due to variation in wind and flooding. Only geese and caribou activity were noted. For these reasons the animal activity data are considered preliminary. They are presented to provide a basis for planning future work to link botanical and wildlife data in habitat evaluation.

Botanical and non-botanical composition near animal fecal material or tracks was determined by taking a subset of transect data. Items were counted that occurred $6 \mathrm{~m}$ on either side of animal signs. Composition was calculated in these subset transects for both botanical and non-botanical items.

\section{Results}

Vegetative cover was $21 \%$ west of the road and $38 \%$ east of the road near the base of the Endicott causeway (Tables 1 and 2). The 3 species most prominent west of the road were Carex subspathacea Wormsk., Salix spp., and Puccinellia phryganodes (Trin.) Scribn. \& Merr. (botanical composition of 26, 23, and $21 \%$, respectively). East of the road Salix spp. (43\%) dominated botanical composition. Carex aquatilis Wahlenb. (13\%) and followed by Dryas integrifolia M. Vahl (11\%).

Both areas were botanically diverse and the botanical composition and plant cover differed. Transects on the west side were not botanically different in composition but were different in total composition (Table 1). The frequency of occurrence on the west side for all objects (plants and non-botanical items) is different between transects and the frequency of occurrence for plants alone occur is different between the individual transects. Transects on the east side of the road were botanically different in composition but did not vary from each other in total composition (Table 2). The east side frequency of occurrence for all objects (plants and non-botanical items) is different, and as well as for plants alone. The same species were not equally represented on both sides of the road and not all species occurred on both sides of the road. The east side was botanically more diverse. The only species occurring on the west side not occurring on the east side were Carex ursina Dew. and Silene acaulis L. Species occurring on the east side of the road but not the west were Chrysanthemum integrifolium Richards., Elymus arenarius (Trin.) Hult., Predicularis spp. and Primula borealis Duby.

Carex subspathacea and Puccinellia phyganodes were 
Table 1. Percent total composition, botanical composition, and frequency of transect occurrence for plants and other objects west of the road near Big Skookum, Prudhoe Bay, Alaska.

\begin{tabular}{|c|c|c|c|}
\hline Item & $\begin{array}{c}\text { Total } \\
\text { Composition }\end{array}$ & $\begin{array}{c}\text { Botanical } \\
\text { Composition }\end{array}$ & Frequency \\
\hline & $\%$ & $\%$ & $\%$ \\
\hline Androsace chamaejasme Hult. & 0.06 & 0.31 & 22.73 \\
\hline Arctophila fulva & 0.31 & 1.48 & 31.82 \\
\hline Anemisia barealis & 0.32 & 1.55 & 27.27 \\
\hline Braya pilosa & 0.01 & 0.03 & 4.55 \\
\hline Carexaquatilis & 0.34 & 1.63 & 22.73 \\
\hline Carex subspathacea & 5.40 & 26.23 & 90.91 \\
\hline Carex ursina & 0.01 & 0.07 & 13.64 \\
\hline Cerastium beeringianum & 0.06 & 0.31 & 22.73 \\
\hline Cochlearia officinalis & 0.70 & 3.39 & 72.73 \\
\hline Draba lactea Adams & 0.13 & 0.64 & 13.64 \\
\hline Drjas integrifolia & 0.41 & 1.98 & 18.18 \\
\hline Eirophorum spp. & 0.01 & 0.03 & 4.55 \\
\hline Lichen (s) & 1.46 & 7.05 & 54.55 \\
\hline Lloydia serotina (L.) Rchb. & 0.10 & 0.50 & 36.36 \\
\hline Oxytropis nigrescens & 0.12 & 0.57 & 9.09 \\
\hline Poa spp. & 0.22 & 1.05 & 13.64 \\
\hline Potentilla hookeriana & 0.38 & 1.84 & 22.73 \\
\hline Puccinellia langeana & 0.58 & 2.80 & 13.64 \\
\hline Puccinellia phryganodes & 4.29 & 20.69 & 100.00 \\
\hline Salix spp. & 4.71 & 22.70 & 72.27 \\
\hline Saxifraga oppositifolia & 0.01 & 0.03 & 9.09 \\
\hline Sedum rosea & 0.17 & 0.84 & 40.91 \\
\hline Silene acaulis & 0.02 & 0.10 & 9.09 \\
\hline Stellaria humifusa Rottb. & 0.11 & 0.52 & 27.27 \\
\hline Wilhelmsia physodes & 0.76 & 3.66 & 77.27 \\
\hline Total plant cover & 21.00 & 100.00 & \\
\hline Bone & 0.00 & & 4.55 \\
\hline Caribou tracks & 0.26 & & 59.09 \\
\hline Drift, small particles & 6.86 & & 100.00 \\
\hline Driftwood, large pieces & 0.61 & & 90.91 \\
\hline Driftwood, small pieces & 1.13 & & 81.82 \\
\hline Fox tracks & 0.01 & & 4.55 \\
\hline Goose droppings & 0.56 & & 86.36 \\
\hline Gravel & 2.97 & & 72.73 \\
\hline Organic matter & 3.39 & & 90.91 \\
\hline Sand & 45.34 & & 100.00 \\
\hline Trash, man-made & 0.06 & & 13.64 \\
\hline Water & 18.07 & & 95.45 \\
\hline Total cover & 100.00 & & \\
\hline
\end{tabular}

observed in over $90 \%$ of the transects west of the road. Salix spp., Cochleria officinalis, L. and Wilhelmsia physodes (Fisch) McNeill were also widely distributed. They were found in over $70 \%$ of the transects. Those most widely distributed east of the road were Oxytropis nigrescense (Pall.) Fisch., Salix spp., and Artemisia borealis Pall. followed by Dryas integrifolia, Cochleria officinalis, and Potentilla hookeriana Lehm.

The plant species highest in frequency of occurrence did not necessarily match those that represented a bigger part of the botanical composition. Wihelmsia physodes west of the road occurs in $77 \%$ of transects but is less that $4 \%$ of the botanical composition. The relation of frequency and botanical composition provides an indication of the relative dispersal and densities of plant species. Carex ursina was widely dispersed but not very dense (occurring on $14 \%$ of the transects and $0.07 \%$ of the botanical composition). It is a plant that grows in small scattered clumps, similar plants to Braya pilosa Hook., Eriophorum spp., Saxifraga oppositifolia (L.) Scop. Carex subspathacea occurred on $91 \%$ of the transects with $26 \%$ botanical composition, it is a plant occurring in dense stands. Puccinellia langeana (Borl.)
Table 2. Percent total composition, botanical composition, and frequency of transect occurrence for plants and other ohjects east of the road near Big Skookum, Prudhoe Bay, Alaska.

\begin{tabular}{|c|c|c|c|}
\hline Item & $\begin{array}{c}\text { Total } \\
\text { Composition }\end{array}$ & $\begin{array}{c}\text { Botanical } \\
\text { Composition }\end{array}$ & Frequency \\
\hline & $\%$ & $\%$ & $\%$ \\
\hline Androsace chamaejasme & 0.31 & 0.83 & 61.90 \\
\hline Arctophila fulva & 0.88 & 2.34 & 28.57 \\
\hline Artemisia borealis & 0.93 & 2.46 & 95.24 \\
\hline Braja pilosa & 0.06 & 0.17 & 28.57 \\
\hline Carex aquatilis & 4.77 & 12.63 & 52.38 \\
\hline Carex subspathacea & 0.84 & 2.23 & 19.05 \\
\hline Cerastium beeringianum & 0.01 & 0.02 & 4.76 \\
\hline Chysanthemum integrifolium & 0.05 & 0.12 & 19.05 \\
\hline Cochlearia officinalis & 0.69 & 1.84 & 76.19 \\
\hline Draba lactea & 0.02 & 0.06 & 4.76 \\
\hline Dryas integrifolia & 4.17 & 11.04 & 85.71 \\
\hline Elymus arenarius & 0.69 & 1.82 & 23.81 \\
\hline Eriophorum spp. & 0.30 & 0.79 & 19.05 \\
\hline Lichen (s) & 0.81 & 2.15 & 52.38 \\
\hline Lloydia serotina & 0.30 & 0.81 & 66.67 \\
\hline Oxytropis nigrescens & 1.46 & 3.87 & 90.48 \\
\hline Pedicularis spp. & 0.12 & 0.33 & 42.86 \\
\hline Poa spp. & 0.20 & 0.54 & 33.33 \\
\hline Potentilla hookeriana & 0.45 & 1.20 & 76.19 \\
\hline Primula borealis & 0.02 & 0.06 & 14.29 \\
\hline Puccinellia langeana & 2.42 & 6.41 & 100.00 \\
\hline Puccinellia pliryganodes & 0.52 & 1.39 & 33.33 \\
\hline Salix spp. & 16.40 & 43.47 & 95.24 \\
\hline Saxifraga oppositifolia & 0.07 & 0.19 & 38.10 \\
\hline Sedum rosea & 0.02 & 0.06 & 9.52 \\
\hline Stellaria humifusa & 0.09 & 0.23 & 23.81 \\
\hline Wihelmsia physodes & 0.09 & 0.25 & 33.33 \\
\hline Total plant cover & 38.00 & 100.00 & \\
\hline Caribou tracks & 0.48 & & 61.90 \\
\hline Drift, small particles & 0.01 & & 4.76 \\
\hline Driftwood, large pieces & 0.07 & & 19.05 \\
\hline Driftwood, small pieces & 0.30 & & 42.86 \\
\hline Goose droppings & 0.22 & & 47.62 \\
\hline Gravel & 0.15 & & 9.52 \\
\hline Organic matter & 0.44 & & 61.90 \\
\hline Sand & 45.79 & & 100.00 \\
\hline Water & 14.80 & & 52.38 \\
\hline Total cover & 100.00 & & \\
\hline
\end{tabular}

Sorens., Puccinellis phyganodes, and Salix spp. occur in dense stands similar to Carex subspathacea. Mixtures of $C$. subspathacea and $P$. phyganodes were also observed. In the east road area Braya pilosa, Cerastium beeringianum Cham. \& Schlecht., Chrysanthemum integrifolium, Primula borealis, and Saxifraga oppositifolia were the most dispersed with Carex aquatilis and Salix spp. the most dense, followed by Carex subspathacea and Dryas integrifolia.

Evidence of caribou activity as measured by presence of tracks was observed on $60 \%$ of the transects on both sides of the road, while goose fecal counts droppings occurred in more $(86 \%)$ of the transects on the west side than on the east side (48\%). Fecal observations are from all goose species and may have included feces from more than 1 year. Tables 3 and 4 summarize the information collected around animal signs. Figure 1 is a detailed map of the area showing the respective distribution of the geese droppings and caribou tracks. The geese droppings tend to be more widely dispersed (greater frequency of occurrence on different transects) than the caribou tracks. Caribou tracks were found on either side of the road equally, the geese droppings more on the west side. Caribou tracks tend to be found more in areas of higher 
Table 3. Percent botanical composition near caribou tracks an goose fecal pellets of transects west of the road near Big Skookum, Prudhoe Bay, Alaska.

\begin{tabular}{|c|c|c|c|}
\hline Item 1 & $\begin{array}{c}\text { Total } \\
\text { botanical } \\
\text { composition }\end{array}$ & $\begin{array}{c}\text { Composition } \\
\text { near caribou } \\
\text { tracks }\end{array}$ & $\begin{array}{c}\text { Composition } \\
\text { near goose } \\
\text { pellets }\end{array}$ \\
\hline & $\%$ & 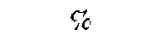 & $\%$ \\
\hline Androsace chamaejasme & 0.31 & & 0.22 \\
\hline Arclophila fulva & 1.48 & 1.94 & 1.25 \\
\hline Artemisia borealis & 1.55 & 0.05 & 1.25 \\
\hline Brava pilosa & 0.03 & & \\
\hline Carex aquatilis & 1.63 & 0.81 & 1.03 \\
\hline Carex subspathacea & 26.23 & 30.65 & 20.23 \\
\hline Carex ursina & 0.07 & 0.86 & 0.06 \\
\hline Cerastium beeringiamum & 0.31 & 0.22 & 0.26 \\
\hline Cachleria officinalis & 3.39 & 0.86 & 3.20 \\
\hline Draba lactea & 0.64 & & 2.05 \\
\hline Drias integrifolia & 1.98 & 0.32 & 0.89 \\
\hline Eriophorum spp. & 0.03 & & 0.04 \\
\hline Lichen (s) & 7.05 & 1.78 & 8.92 \\
\hline Lloydia serotina & 0.50 & 0.76 & 0.87 \\
\hline Onytropis nigrescens & 0.57 & & 0.89 \\
\hline Poa spp. & 1.05 & & 0.87 \\
\hline Putentilla hookeriana & 1.84 & & 1.75 \\
\hline Puccinellia langeana & 2.80 & & 2.34 \\
\hline Puccinellia pliryganodes & 20.69 & 30.55 & 21.58 \\
\hline Salix spp. & 22.70 & 11.93 & 27.82 \\
\hline Saxifraga opposinifolia & 0.03 & & 0.02 \\
\hline Sedim rosea & 0.84 & 0.11 & 0.40 \\
\hline Silene acaulis & 0.10 & & 0.06 \\
\hline Stellaria humifusd & 0.52 & & 0.26 \\
\hline Wilhelmsia plinsodes & 3.66 & 19.16 & 3.74 \\
\hline Totals & 100.00 & & \\
\hline
\end{tabular}

Botanical compostion near caribou tracks and govie pellets is different than botanical composituon in the area $(P<01)$. Botanical compostuon near caribou tracks is different than botanical compoition near goose pellets $(P<\theta)$.

elevation and the geese droppings are nearer water. Botanical composition near caribou tracks and geese pellets is different from botanical composition as a whole on both sides of the road. Botanical composition on either side of the road was different in areas with caribou tracks than those areas with geese droppings. The areas containing caribou tracks on the west side of the road were predominately Carex subspathacea. Puccinellia phryganodes, Wilhelmsia physodes, and Salix spp. The geese droppings, in contrast, occurred in arcas populated with Salix spp., Puccinellia phryganodes, Carex subspathecea, and Lichen(s). On the east side of the road there was a different pattern for both geese droppings and caribou tracks. Caribou tracks were found in areas with Salix spp., Puccinellia langeana. Dryas integrifolia, and Sedum rosea (L.) Scop. The geese pellets were in areas of Salix spp., Dryas integrifolia, Oxtyropis nogrescens, and Carex aquatilis. Geese pellets did occur in areas with Arctophila fulla (Trin.) Anderss. and Dryas integrifolia on the east but not the west side of the road. Caribou tracks were in areas of Caxer subspathacea and Puccinellia plryganodes on the west but not the east side of the road. Comparison of east and west road and geese droppings versus caribou tracks indicated no difference in the non-botanical composition (Table 5), although goose droppings tended to be closer to water.

\section{Discussion and Conclusions}

Transect characterization of an area provides information that is strictly relevant to the time when the measurements were taken.
Table 4. Percent botanical composition near caribou tracks and goose fecal pellets of transect east of the road near Big Skookum, Prudhoe Bay, Alaska.

\begin{tabular}{|c|c|c|c|}
\hline Item $^{1}$ & $\begin{array}{c}\text { Total } \\
\text { botanical } \\
\text { composition }\end{array}$ & $\begin{array}{c}\text { Composition } \\
\text { near caribou } \\
\text { tracks }\end{array}$ & $\begin{array}{c}\text { Composition } \\
\text { near goose } \\
\text { pellets }\end{array}$ \\
\hline & $\%$ & $\%$ & $\%$ \\
\hline Androsace chamaejasme & 0.83 & 0.44 & 0.85 \\
\hline Arctophila fulva & 2.34 & & 3.64 \\
\hline Artemisia borealis & 2.46 & 3.77 & 2.2 \\
\hline Braya pilosa & 0.17 & 0.19 & .59 \\
\hline Carex aquatilis & 12.63 & 0.06 & 8.04 \\
\hline Carex sibspathacea & 2.23 & 0.88 & \\
\hline Cerastium beeringianum & 0.02 & & \\
\hline Chrysanthemum integrifolium & 0.12 & 0.06 & 0.25 \\
\hline Cochleria officinalis & 1.84 & 5.72 & 2.54 \\
\hline Draba lactea & 0.06 & & \\
\hline Dnyas integrifolia & 11.04 & 9.18 & 20.91 \\
\hline Elymus arenarius & 1.82 & 1.89 & \\
\hline Eriophorum spp. & 0.79 & & 0.85 \\
\hline Lichen (s) & 2.15 & & 2.62 \\
\hline Lloydia serotina & 0.81 & 1.95 & 0.51 \\
\hline Oxytropis nigrescents & 3.87 & 4.47 & 8.55 \\
\hline Pedicularis spp. & 0.33 & 0.06 & 0.68 \\
\hline Poa spp. & 0.54 & 1.95 & 0.17 \\
\hline Potentilla hookeriana & 1.20 & 3.21 & 0.85 \\
\hline Primula borealis & 0.06 & 0.06 & \\
\hline Puccinellia langeana & 6.41 & 12.96 & 6.27 \\
\hline Puccinellia phryganodes & 1.39 & 1.19 & 0.42 \\
\hline Salix spp. & 43.47 & 42.64 & 36.83 \\
\hline Saxifraga oppositifolia & 0.19 & 0.19 & $0.0 \mathrm{~S}$ \\
\hline Sedum rosea & 2.71 & 7.86 & 2.2 \\
\hline Stellaria humifusa & 0.23 & 0.88 & 0.34 \\
\hline Wilhelmsia physodes & 0.25 & 0.38 & 0.51 \\
\hline
\end{tabular}

${ }^{1}$ Botanical composition near caribou tracks and goose pellets is different than botanical composition in the area $(P<01)$. Botanical composition near caribou tracks is different than botanical composition near goose pellets $(P<.01)$.

A series of transects over years would allow some conclusions to be drawn regarding changes in the botanical composition related to weather, grazing activity, construction, etc.

Table 5. Percent non-botanical composition near caribou tracks and goose fecal pellets of transects west and east of the road near Big Skookum, Prudhoe Bay, Alaska.

\begin{tabular}{llccc}
\hline \hline Item 1 & & $\begin{array}{c}\text { Total } \\
\text { botanical } \\
\text { composition }\end{array}$ & $\begin{array}{c}\text { Composition } \\
\text { near caribou } \\
\text { tracks }\end{array}$ & $\begin{array}{c}\text { Composition } \\
\text { near goose } \\
\text { pellets }\end{array}$ \\
\hline West & & & \\
& Plant material & 20.73 & 21.43 & 25.96 \\
& Caribou tracks & 0.26 & 4.47 & 0.18 \\
& Driftwood & 8.61 & 5.99 & 9.83 \\
& Goose droppings & 0.56 & 0.40 & 3.11 \\
& Gravel/Sand & 48.31 & 60.6 & 51.1 \\
& Organic matter & 3.39 & 4.75 & 5.02 \\
& Misc & 0.06 & none & 0.27 \\
Water & 18.07 & 2.35 & 4.53 \\
East & & & \\
& Plant material & 37.74 & 21.78 & 37.03 \\
& Caribou tracks & 0.48 & 3.26 & 0.06 \\
Driftwood & 0.38 & 0.07 & 0.44 \\
Goose droppings & 0.22 & 0.03 & 3.29 \\
Gravel/Sand & 45.94 & 73.44 & 38.23 \\
Organic matter & 0.44 & 0.10 & 0.03 \\
Water & 14.08 & 1.33 & 20.92 \\
\hline
\end{tabular}

Non-botanical composition values are not different, east road or west road. for geese or caribou. $(P>.9)$. 
The salt-affected coastal tundra area studied was only 20 to $30 \%$ cover, apparently not having the capacity to produce or sustain a more dense plant cover. A majority of the plants present have not been identified as being in the diet of the geese (Sedinger and Raveling, 1984). The most important plant in the geese diet as observed by Sedinger and Raveling (1984) was Triglochin palustris $\mathrm{L}$. and it did not occur in this area. The most common sedge used by the geese in the Sedinger and Raveling study (1984) was Carex mackenziei Krecz. and it did not occur here either. The botanical composition near the animal signs indicate they are in areas that on a whole are different from the general area. The animals using the area might, through selective grazing, get greater nutritional value than would be immediately apparent (Sedinger, 1984). The geese droppings were more prevalent on the west side of the road, but since the west road and east road areas were different botanically no inference can be made whether the road was a barrier or habitat difference or something else. The habitat difference as well as the presence of the road might have affected the difference in the number of goose droppings on 1 side versus the other. The road did not appear to be a barrier to the caribou as evidenced by near equal frequency of tracks on either side of the road. There was no clear association between caribou tracks or goose pellets and a particular plant species. The vegetation does not seem to influence the presence of either caribou or geese in a particular spot in this area and they used different parts of this study area. The vegetation in this area is not dense and does not contain the species caribou or geese are known to prefer in large amounts. There are however areas within $50 \mathrm{~m}$ that do contain these plants in large quantities. These animals probably prefer this area for reasons other than dietary needs.

This area is sparsely covered and the plants known to be present that are in the animal's diet are not concentrated. The area's value to animals is probably for something besides diet. The road does not appear to affect the presence of caribou tracks, and no inferences can be made about goose droppings. The area should be further studied to delineate its attraction for geese and caribou before any assessment can be made of habitat loss to either.

\section{Literature Cited}

Burgess, R.M. and R.J. Titchie. 1988. Snow Geese: 1988 Endicott Environmental Monitoring Program, Sci. Appl. Int. Corp., Anchorage, Alaska.

Chapin, F.S. III, K. VanCleve, and L.L. Tieszen. 1975. Seasonal nutrient dynamics of tundra vegetation at Barrow, Alaska. Arctic and Alpine Research 2:209-226.

Derksen, Dirk V., W.D. Eldrige, and M.W. Weller, 1982. Habitat ecology of Pacific Black Brant and other geese molting near Teshekpuk Lake, Alaska. Wildfowl 33:39-57

Eberhardt, L.E., W.C. Hanson, J.L. Bengston, R.A. Garrott, and E.E. Hanson. 1982. Arctic fox home range characteristics in and oil development area. J. Wildl. Manage. 46:183-190.

Giroux, J-F., Y. Bedard, and J. Bedard. 1984. Habitat use by greater Snow Geese during the brood-rearing period. Arctic 37:155-160.

Harwood, J. 1977. Summer feeding ecology of lesser snow geese. J. Wildl. Manage. 41:48-55.

Sedinger, J.S. 1984. Protein and amino acid composition of tundra vegetation in relation to nutritional requirements of geese. J. Wild. Manage. 48:1128-1136.

Sedinger, J.S., and D, G. Raveling. 1984. Dietary selectivity in relation to availability and quality of food for goslings of crackling geese. The Auk 101:295-306.

Wilkinson, R.C. and K. Kertell. 1991. Snow Geese habitat assessment. North Slope Studies Workshop, British Petroleum Exploration (Alaska) Inc.

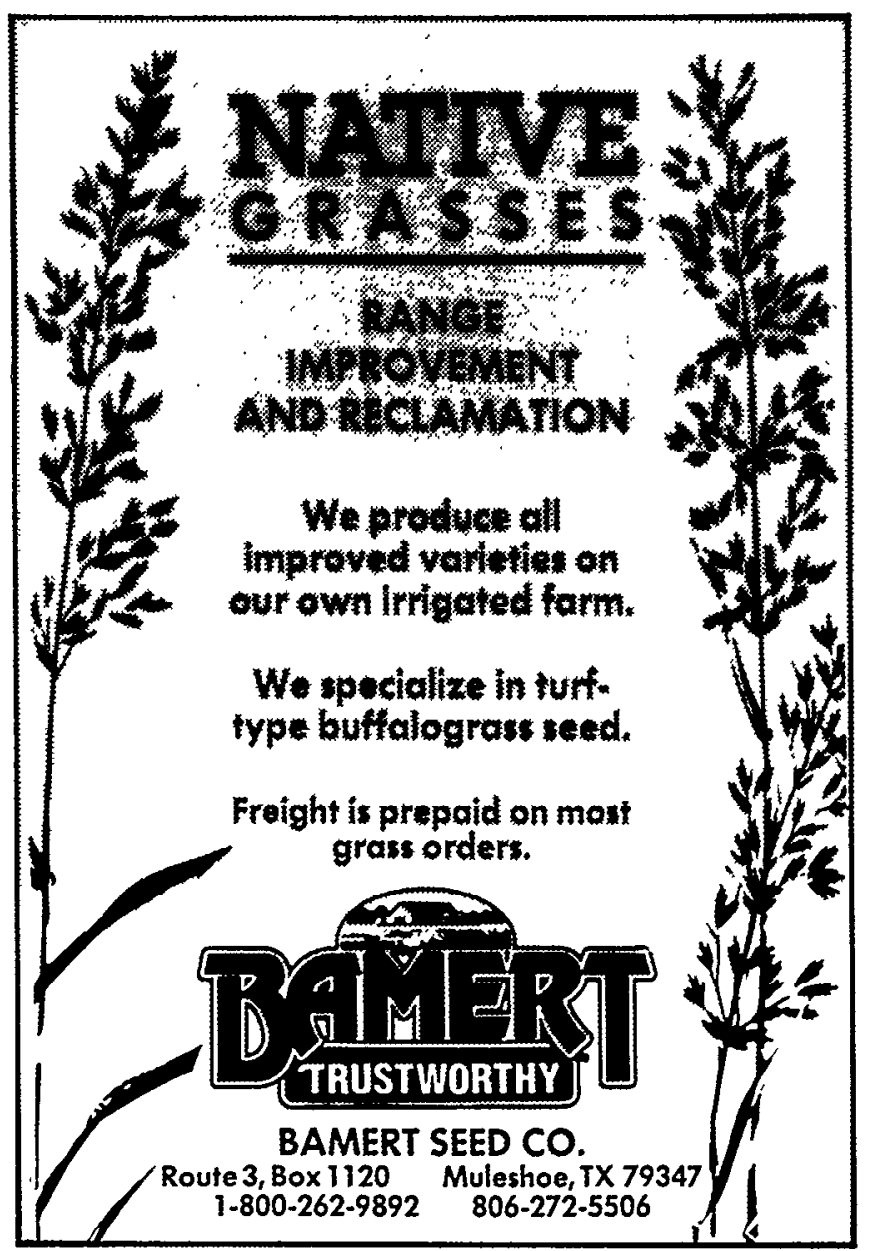

